\title{
INFORMATION VALUE OF PATENT LITIGATION AND INDUSTRY COMPETITION IN TAIWAN
}

\author{
Jun-De LEE ${ }^{a}$, Yi-Hsien WANG ${ }^{b}$, Ching-Wen LINc, Hsin-Ham LIN ${ }^{\mathrm{d}}$ \\ a Department of International Business, Minghsin University of Science and Technology, HsinChu, Taiwan \\ ${ }^{\mathrm{b}}$ Department of Banking \& Finance, Chinese Culture University, Taipei, Taiwan \\ ${ }^{c, \mathrm{~d}}$ Department of International Business Administration, Chinese Culture University, Taipei, Taiwan
}

Received 02 September 2011; accepted 14 April 2012

\begin{abstract}
Internationally, news on patent infringement is often seen, and patent infringement lawsuits affect stock prices. However, fewer studies have discussed how market reflects corporate value and impact of patent infringement lawsuit on investment returns when a patent infringement lawsuit occurs and the news is released. This study applied event study to discuss changes in information value of plaintiffs and defendants, and information value difference of different patent lawsuit sources in competitive environment. The empirical results showed that patent infringement lawsuits may cause negative perception of investors or insider shareholders. This event may become an arbitrage opportunity. Through five forces analysis, the lawsuits from various sources are bad news. Reverse correction is conducted after the event, and makes stock price rational. Thus, in Taiwan market, patent infringement lawsuit is negative news for plaintiff and defendant.
\end{abstract}

Keywords: patent infringement litigation, information value, enterprise competition, abnormal return.

Reference to this paper should be made as follows: Lee, J.-D.; Wang, Y.-H.; Lin, C.-W.; Lin, H.-H. 2013. Information value of patent litigation and industry competition in Taiwan, Technological and Economic Development of Economy 19(4): 593-605.

JEL Classification: C21, G14, O31.

\section{Introduction}

In an information society, the global economy has witnessed the transition from industrial age to knowledge-based economy age. According to the definition of the Organization for Economic Cooperation and Development (OECD), knowledge-based economy is directly based on the production, distribution and use of knowledge and information (David, Foray 2002;

Corresponding author Yi-Hsien Wang

E-mail: holland@mail2000.com.tw 
Shinn 2002; Godin 2004; Velmurugan 2010; Capik, Drahokoupil 2011). The corporations can develop exclusive right of product or even use patent right or patent infringement to create profit and maintain competitiveness when they obtain patent right. However, patent infringement lawsuits are lengthy and costly. It is trans-market and transational, and requires a considerable amount of legal fee. Companies should have strong financial strength to face revenue loss and market risk (Cohen et al. 2002; Langinier, Marcoul 2009; Tseng et al. 2009; Galasso, Schankerman 2010; Lo 2011).

Infringement lawsuits are common in recent years. In the long litigation process, for investors, both plaintiff and defendant have highly uncertain market information. Many studies have focused on the impact of lawsuits on stock price or shareholder wealth (Banks, Kinney 1982; Frost 1991; Koku et al. 2001; Shane, Somaya 2007; Cockburn, MacGarvie 2009). When an enterprise is charged or files lawsuit, due to the impact of news release on psychology of investors, they concern about future corporate operation and have uncertain reaction, resulting in stock price volatility and serious shock to enterprise. However, investment information caused by information value of infringement lawsuit is not always negative. If the enterprise has specific patents, patent portfolios can be extended to other market, which is a key to lawsuit response strategy (Bhagat, Romano 2002; Somaya 2003; Marco 2005; Bessen, Meurer 2006; Raghu et al. 2008; Siebert, Graevenitz 2010).

Past studies have explored the impact of patent infringement lawsuits of information industry and judgments on stock price volatility (Raghu et al. 2008; Konchitchki, O'Leary 2011). For listed companies in Taiwan, the empirical results suggested that patent lawsuits have a negative impact on stock price. From filing lawsuits for patent infringement to making the lawsuits publically known, information disclosure may affect financial market (Agarwal et al. 2009; Chen, Chang 2010; Wagner, Cockburn 2010). This is due to advanced release of information. Investors may believe that the lawsuits would affect the normal operation of the company, even cause bankruptcy, so they tend to have negative views on the lawsuits. When global industrial output value depends on intangible asset, patent infringement lawsuits have become increasingly important, and even affect the national economy (Lanjouw, Schankerman 2001; Raghu et al. 2008).

Patents can enhance industrial competitiveness, but long-drawn litigation processes increase uncertainty. This means that more investment risks can affect stock market. Current studies have focused on measuring patent and innovation capabilities (Megna, Klock 1993; Hirschey, Richardson 2001; Hall, Bagchi-Sen 2002; Lanjouw, Schankerman 2004; Chiu, Chen 2007; Ernst et al. 2010; Agliardi, E., Agliardi, R. 2011; Suzuki 2011). However, patent lawsuits often occur overseas, and the newspaper coverage may be delayed. When lawsuits occur, with transmission of news, market reaction and the impact of patent infringement lawsuit on companies should be explored (Jang, Chen 2009; Konchitchki, O’Leary 2011). In addition, industrial difference may affect the reactions of listed companies' stock prices.

Only fewer studies have explored stock price behaviour responses to patent litigation (Raghu et al. 2008). Therefore, in this study, we examine not only the stock price impact of patent litigation, but also adopt the viewpoint of industrial competitiveness, Porter's Five Forces of Competitive Position Model (Porter 1980), to integrate patent development and financial economics through the empirical case in Taiwan. Thus, the purpose of this study 
is to explore the changes in information value of plaintiff and defendant when discussing patent lawsuit. Second, we discuss the information value difference of different patent lawsuit sources in a competitive environment and determine the financial factors affecting cumulative abnormal returns of different lawsuit sources. This paper is organized as follows. Section 1 presents the data selection and market model. Next, section 2 presents empirical evidence. Finally, the last section discusses the results and presents conclusions.

\section{Methodology}

\subsection{Data Selection}

Following Taiwanese electronic industry gradually integrated into the global supply chain, electronic industry has been the engine of rapid economic growth. Today, Taiwan has become the world's fourth largest supplier for the electronic industry that provides evidence of the importance of electronic industry to economic development in Taiwan (Malerba, Nelson 2011). Thus, this study investigates the listing and OTC electronic companies in Taiwan. The data are sourced from UDNDATA, and searched by the key words of "patent, infringement, suit, charge, defendant and lawsuit". The patent infringement lawsuit news during the period from January 1, 1998 to October 31, 2010 is selected as samples. The samples are compared with the Market Observation Post System, and are selected according the following criteria. First, the stock price data having no estimation period and event period are not included. Moreover, if the same event is declared repeatedly, the first event is selected. To avoid confounding effect, if the announcement period is too close, for the data which the first announcement date and the second estimation period is repeated, the second data is not selected. After deleting repeated announcements and insufficient estimation period, the number of plaintiff samples is 39 , and the number of defendant samples is 120 .

Based on Porter's Five Forces of Competitive Position Model and electronic industry flow chart, this study divides the lawsuit sources into vendors, purchasers, and industry competitors by upstream and downstream industry. The non-electronic industry or the undefined sources are listed as potential competitor, as shown in Figure 1. As seen, most patent suits are filed by the upstream and the downstream and competitive manufacturers.

\subsection{The market model}

The event study methodology has been widely used in different events (Raghu et al. 2008; Konchitchki, O'Leary 2011). The recent event study methodology is often used in accounting and financial fields, such as announcement of merger and acquisition, important investment event, lawsuit and capital increase by cash (Fama 1969; Corhay, Tourani 1994; Pantzalis et al. 2000; Chen, Su 2010; Lai et al. 2010; Chuang, Wang 2010; Asgharian et al. 2011; Cheung 2011). The event study methodology aims to discuss whether the occurrence of some event affects abnormal change of stock price and causes excess returns (Yang et al. 2010; Li, Tallman 2011). The information can be used to determine whether market securities price and specific event is correlated. 

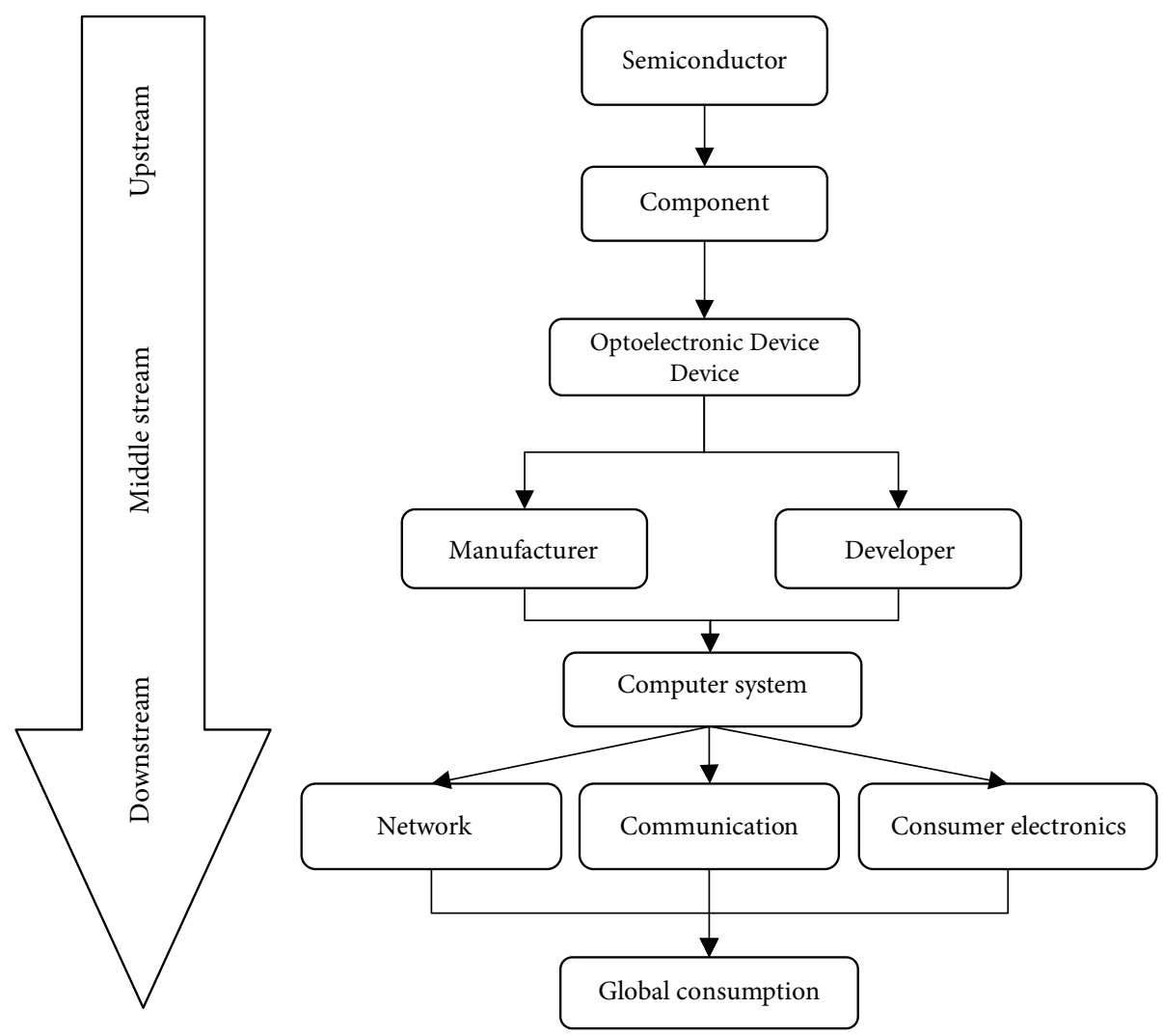

Fig. 1. The electronic industrial structure

The market model was proposed by Sharpe (1964), and it assumes that the rate of returns on individual securities and market investment portfolio have linear relationship. Brown and Warner (1985) compared various methods, and found that market model is a better approach (Lin et al. 2008; Campbell et al. 2010). This study uses market model to discuss the reaction when patent infringement is reported in newspapers, and lawsuits are filed to court. This model is a linear model expressing relations between corporations.

$$
R_{i t}=\alpha_{i}+\beta_{i} R_{m t}+\varepsilon_{i t},
$$

where: $R_{i t}$ is the returns on the $i$ stock in the $t$ period; $R_{m t}$ is the returns on stock market in the $t$ period; $\alpha_{i}$ is the constant term of market scale; $\beta_{i}$ is used to measure effect of change in market returns on returns on individual stock. Excess return means the difference between actual return rate and expected return rate when event occurs, and the difference is called abnormal return (AR). It aims to discuss whether the event causes excess returns on sample stocks. The two parameters, $\alpha_{i}$ and $\beta_{i}$ are estimated in market model, and substituted in stock return and market return, $A R_{i t}=R_{i t}-\hat{\alpha}_{i}-\hat{\beta}_{i} R_{m t}$. 
Average excess returns (ARR) refers to the summation of day excess returns of all event samples divided by number of samples. The equation is as follows:

$$
\overline{A R}_{t}=\frac{1}{N} \sum_{i=1}^{N} A R_{i t},
$$

where: $\overline{A R}_{t}$ is the average excess returns of the $t$ day; $N$ is the number of samples. To determine the cumulative effect or excess returns during some specific period, the average excess returns in some specific time during the observation period are accumulated to obtain cumulative abnormal return (CAR). The equation is as follows:

$$
C A R_{i}(\tau)=\frac{1}{N} \sum_{t=\tau_{1}}^{\tau_{2}} \sum_{i=1}^{N} A R_{i t},
$$

where: $N$ is the number of samples, and $\tau$ is the verification period $\left(=\tau_{2}-\tau_{1}\right)$.

\subsection{Multiple regression model}

This study uses a multiple regression model to discuss the factors affecting abnormal returns. The samples are classified into different sources of lawsuits to verify the company's financial performance measures. Previous studies in Taiwan have used operating efficiency, growth, profitability, debt paying ability and equity structure to analyse financial ratio. This study uses the following six terms as the independent variables of cross-sectional analysis.

$$
C A R_{i}=\alpha+\beta_{1} R T+\beta_{2} A I T+\beta_{3} R O A+\beta_{4} E P S+\beta_{5} C R+\beta_{6} Q R
$$

where: $C A R_{i}$ is the cumulative abnormal returns of event window period; $R T$ is the receivables turnover rate $(R T)$ that evaluates how operating efficiently sample uses its assets, $R T=$ Net Credit Sales / Average Accounts Receivable; AIT is the average inventory turnover rate (AIT) that measures the relationship between the cost of goods sold during a sample period of time and the cost of average inventory during a sample period, $A I T=$ Cost of goods sold / Average inventory at cost; $R O A$ is the return on total assets ratio $(R O A)$ that defines how profitable sample is relative to its total assets, $R O A=$ Net Income / Total Assets; EPS is the earnings per share $(E P S)$ that a measure indicator of sample profitability, EPS $=($ Net Income - Dividends on Preferred Stock) / Average Outstanding Shares; $C R$ is the current ratio (CR) that is measured by dividing current assets by current liabilities, $C R=$ Working Capital / Current Liabilities; $Q R$ is the quick ratio $(Q R)$ calculated by dividing current assets from which inventory has been excluded, by current liabilities, $Q R=($ Cash + Marketable Securities + Accounts Receivable) / Current Liabilities; $\beta_{i}$ are regression parameters, and these financial historical data were collected from TEJ database (Taiwan Economics Journal). 


\section{Preliminary analysis and empirical result}

This study divides plaintiff and defendant into vendors, purchasers, industry competitors, and potential competitors. Due to insufficient plaintiffs, only defendants are used in sample analysis. On the date of filing a suit, the excess returns of the different enterprises are shown in Table 1 . For vendors, AR reaches $5 \%$ significance level on the -15 th day and the -10 th day $(-1.299,1.100)$. This means that the suit is disclosed on -15 th day. The investors or insider shareholders have a negative impact on the event. The reaction is too strong, and excess returns are modified to be positive value. On the 2 nd day and the 4 th day, there is a significant negative impact, and significant level is reached on the -15 th day, the -14 th day and the -13 th day of CAR event. This means that news is disclosed in advance. For purchasers, AR reaches a significance level and has a positive impact on the -4 th day, indicating that insider shareholders are optimistic about the suit. On the 1 st day and the 2 nd day of the event $(-0.715,-0.715)$, the returns have significant negative impact and are modified to significant positive impact on the 5th day after the event, indicating that the suit is considered negative news for companies. CAR fails to reach a significance level. For industry competitors, AR shows a significant negative impact on the -14 th day (-1.173), and has a significant positive impact on the -5 th day (1.038), and a significant negative impact on the 1 st day after the event (-0.722). CAR shows a significant negative impact for many days. It can be found that lawsuit has an adverse impact on stock price. For potential competitors, AR show a significant negative impact on the -11 th day and the -12 th day $(-1.002,-0.975)$, and a significant positive impact on the -2 nd day, 0 day, the 2 nd day, 5 th day, 8 th day and 14 th day. Investors have negative views on potential companies, and are confident about the defendant, which are positive impact. CAR shows significant negative impact for many days due to lawsuit. Although CAR fails to reach significant level after event, it shows positive impact. It can be seen that investors are confident about the defendant.

Table 1. Patent infringement from different sources

\begin{tabular}{|c|c|c|c|c|c|c|c|c|}
\hline & \multicolumn{2}{|c|}{ Supplier } & \multicolumn{2}{|c|}{ Customers } & \multicolumn{2}{|c|}{ Competitive rivalry } & \multicolumn{2}{|c|}{$\begin{array}{c}\text { Potential } \\
\text { Competitors }\end{array}$} \\
\hline & $\mathrm{AR}$ & CAR & AR & CAR & $\mathrm{AR}$ & CAR & AR & CAR \\
\hline-15 & $-1.299^{\star *}$ & $-1.299^{*}$ & 0.136 & 0.136 & 0.002 & 0.002 & -0.538 & -0.538 \\
\hline-14 & -0.055 & $-1.354^{\star}$ & -0.115 & 0.021 & $-1.173^{\star \star}$ & $-1.171^{\star *}$ & -0.676 & -1.214 \\
\hline-13 & -0.137 & $-1.492^{\star}$ & -0.137 & -0.116 & 0.138 & -1.032 & -0.288 & -1.502 \\
\hline-12 & -0.795 & -0.695 & -0.330 & -0.446 & 0.278 & -0.754 & $-1.002^{\star}$ & $-2.505^{\star \star}$ \\
\hline-11 & -0.088 & -0.784 & -0.164 & -0.611 & -0.617 & -1.371 & $-0.975^{\star}$ & $-3.480^{\star * \star}$ \\
\hline-10 & $-1.100^{\star *}$ & -0.315 & 0.551 & -0.060 & -0.198 & -1.569 & -0.205 & $-3.686^{\star * *}$ \\
\hline-9 & -0.274 & 0.041 & -0.434 & -0.494 & 0.008 & -1.561 & -0.512 & $-4.199^{* * *}$ \\
\hline-8 & -0.111 & 0.153 & 0.113 & -0.381 & 0.086 & -1.475 & 0.200 & $-3.998^{\star * *}$ \\
\hline
\end{tabular}


Continued Table 1

\begin{tabular}{|c|c|c|c|c|c|c|c|c|}
\hline & \multicolumn{2}{|c|}{ Supplier } & \multicolumn{2}{|c|}{ Customers } & \multicolumn{2}{|c|}{ Competitive rivalry } & \multicolumn{2}{|c|}{$\begin{array}{c}\text { Potential } \\
\text { Competitors }\end{array}$} \\
\hline & $\mathrm{AR}$ & CAR & $\mathrm{AR}$ & CAR & $\mathrm{AR}$ & CAR & $\mathrm{AR}$ & CAR \\
\hline-7 & -0.301 & 0.455 & 0.465 & 0.083 & -0.595 & $-2.071^{\star}$ & -0.259 & $-4.258^{\star * *}$ \\
\hline-6 & -0.223 & 0.678 & 0.013 & 0.097 & 0.089 & -1.980 & 0.602 & $-3.655^{\star *}$ \\
\hline-5 & -0.631 & 0.047 & 0.165 & 0.262 & $1.038^{\star \star}$ & -0.943 & -0.187 & $-3.842^{\star *}$ \\
\hline-4 & -0.380 & 0.428 & $0.849^{\star *}$ & 1.112 & 0.501 & -0.441 & 0.024 & $-3.818^{\star *}$ \\
\hline-3 & -0.024 & 0.452 & 0.281 & 1.393 & 0.124 & -0.317 & 0.066 & $-3.752^{\star}$ \\
\hline-2 & -0.820 & -0.368 & -0.088 & 1.305 & -0.194 & -0.512 & $1.133^{\star *}$ & -2.618 \\
\hline-1 & -0.247 & -0.120 & -0.302 & 1.002 & -0.471 & -0.984 & 0.367 & -2.251 \\
\hline 0 & -0.144 & -0.265 & -0.430 & 0.572 & -0.568 & -1.552 & $0.935^{\star}$ & -1.310 \\
\hline 1 & -0.141 & -0.124 & $-0.715^{\star *}$ & -0.142 & $-0.722^{\star}$ & -2.274 & 0.351 & -0.965 \\
\hline 2 & $-0.985^{\star}$ & -1.109 & $-0.715^{\star *}$ & -0.247 & -0.25 & -2.524 & $1.070^{\star}$ & 0.104 \\
\hline 3 & -0.331 & -0.777 & 0.258 & 0.011 & -0.602 & $-3.127^{\star}$ & -0.302 & -0.197 \\
\hline 4 & $-1.042^{\star \star}$ & -1.820 & $-0.215^{\star * *}$ & -0.204 & 0.452 & -2.674 & 0.195 & -0.002 \\
\hline 5 & -0.547 & -2.367 & 1.063 & 0.859 & -0.474 & $-3.148^{\star}$ & $1.029^{*}$ & 1.086 \\
\hline 6 & $-0.919^{\star}$ & -3.286 & 0.006 & 0.865 & -0.307 & $-3.455^{\star}$ & 0.059 & 1.086 \\
\hline 7 & $-0.851^{\star}$ & -2.435 & -0.14 & 0.451 & -0.375 & $-3.831^{\star}$ & 0.479 & 1.565 \\
\hline 8 & -0.294 & -2.141 & -0.235 & 0.215 & $-0.683^{\star}$ & -3.147 & $1.274^{\star \star}$ & 2.840 \\
\hline 9 & -0.567 & -1.570 & -0.027 & 0.188 & 0.070 & -3.077 & 0.523 & 3.364 \\
\hline 10 & -0.609 & -2.183 & -0.146 & 0.041 & 0.169 & -2.907 & 0.472 & 3.836 \\
\hline 11 & $-1.225^{\star *}$ & -0.958 & -0.214 & -0.172 & 0.375 & -2.531 & 0.161 & 3.997 \\
\hline 12 & -0.051 & -1.010 & 0.089 & -0.083 & -0.003 & -2.535 & -0.215 & 3.782 \\
\hline 13 & -0.660 & -0.350 & -0.246 & -0.330 & -0.638 & -3.173 & -0.262 & 3.520 \\
\hline 14 & -0.408 & 0.058 & -0.185 & -0.516 & -0.543 & $-3.717^{\star}$ & $0.946^{\star}$ & 4.466 \\
\hline 15 & -0.099 & 0.157 & 0.397 & -0.118 & -0.060 & $-1.777^{\star}$ & -0.059 & 4.407 \\
\hline
\end{tabular}

Notes: $1 .{ }^{\star \star \star}$ denotes statistical significance at $1 \%$ level. $2 .{ }^{\star \star}$ denotes statistical significance at $5 \% .3{ }^{\star}$ denotes statistical significance at $10 \%$.

Regardless of lawsuit sources, patent lawsuits lead to negative perception of investors, and affect stock prices. After the event, reverse correction is conducted, and makes stock price rational, thus bringing investors an arbitrage opportunity. Overall, patent lawsuit is bad news for enterprises. 
This study uses the multiple regression model to discuss the factors affecting abnormal returns, divides the samples into different sources of lawsuits to verify company financial performance measure, and utilizes operating efficiency, growth, profitability, debt paying ability and equity structure for analysis. Table 2 shows whether CAR is significant in various window periods. In lawsuits by vendors, negative abnormal returns reach a significance level in window periods $(0,4),(0,5)$ and $(0,6)$. In lawsuits by purchasers, negative returns reaches a significance level in window periods $(2,1),(-1,1)$ and $(0,1)$. In lawsuits by industry competitors, negative abnormal returns are more significant than vendors and purchasers in window periods. In lawsuits by potential competitors, significant positive abnormal returns are found in many periods. For investors, the lawsuits by potential competitors can lead to positive returns, and differ from the first three.

Table 2. Window analysis for patent infringement litigation

\begin{tabular}{|c|c|c|c|c|c|}
\hline \multicolumn{3}{|c|}{ Supplier } & \multicolumn{3}{|c|}{ Customers } \\
\hline period & CAR & t-value & period & CAR & $\mathrm{t}$-value \\
\hline$(-1,0)$ & 0.1028 & -0.1672 & $(-5,0)$ & -0.4752 & -0.5931 \\
\hline$(0,1)$ & -0.0034 & -0.0044 & $(-2,1)$ & -1.5361 & $-2.0063^{\star}$ \\
\hline$(0,4)$ & -1.6997 & $-1.9846^{\star}$ & $(-1,1)$ & -1.4479 & $-2.0548^{\star *}$ \\
\hline$(0,5)$ & -2.2468 & $-2.0762^{\star}$ & $(0,1)$ & -1.1453 & $-1.7517^{\star}$ \\
\hline$(0,6)$ & -3.1659 & $-2.2785^{\star *}$ & $(0,2)$ & -1.2501 & -1.4481 \\
\hline \multicolumn{3}{|c|}{ Competitive rivalry } & \multicolumn{3}{|c|}{ Potential Competitors } \\
\hline period & CAR & t-value & period & CAR & $\mathrm{t}$-value \\
\hline$(0,1)$ & -1.2906 & $-1.9100^{\star}$ & $(-2,0)$ & 2.4347 & $2.2493^{\star \star}$ \\
\hline$(0,2)$ & -1.5405 & $-1.7518^{\star}$ & $(0,5)$ & 3.2778 & $2.3142^{\star \star}$ \\
\hline$(0,3)$ & -2.1430 & $-2.1192^{* *}$ & $(-1,5)$ & 3.6449 & $2.2548^{\star *}$ \\
\hline$(-1,3)$ & -2.6150 & $-2.5872^{\star \star}$ & $(-2,5)$ & 4.7780 & $2.5040^{* *}$ \\
\hline$(-1,2)$ & -2.8098 & $-2.4532^{\star *}$ & $(-3,5)$ & 4.8443 & $2.6065^{\star \star}$ \\
\hline
\end{tabular}

Notes: $1 .{ }^{* *}$ denotes statistical significance at $1 \%$ level. $2 .{ }^{* *}$ denotes statistical significance at $5 \% .3 .{ }^{*}$ denotes statistical significance at $10 \%$.

This study then selects more significant window periods, vendors $(0,4)$, purchasers $(-1,1)$, industry competitors $(-1,3)$ and potential competitors $(0,5)$ for regression analysis to determine other factors affecting excess returns. Table 3 shows that significance level is not reached in lawsuit by vendors. Table 3 shows that patent infringement behaviour has a significant negative impact on inventory turnover rate, and inventory may be affected if purchasers file a suit. Table 3 indicates that return on total assets ratio, earnings per share and current ratio are negatively significant, while patent infringement lawsuit by industry competitors have significant impact on enterprises. Table 3 shows that earnings per share is positively significant, and current ratio is negatively significant in lawsuit by potential competitors. Overall, lawsuits by potential competitors can cause earnings per share to have positive returns, and provide an arbitrage opportunity. Under pressure of production and downstream, supplier utilized 
patent litigation as the strategic behaviour to prevent new competitors and unstable supply threats. Hence, these ex post explanatory variables had insignificantly impact on CAR while patent infringement lawsuit by supplier to avoid potential competitive threats.

Table 3. Cross-section analysis for patent infringement litigation

\begin{tabular}{lllll}
\hline \multicolumn{1}{c}{ Variable } & Supplier & Customers & $\begin{array}{c}\text { Competitive } \\
\text { rivalry }\end{array}$ & $\begin{array}{c}\text { Potential } \\
\text { Competitors }\end{array}$ \\
\hline Accounts receivable turnover & -1.1401 & -3.5620 & -0.2382 & -1.5845 \\
\hline Inventory Turnover & 1.7059 & $-4.5153^{\star *}$ & $-5.0315^{\star}$ & -0.0034 \\
\hline Return on total assets & -0.8543 & -0.0011 & $-1.1619^{* *}$ & -0.1280 \\
\hline Earnings per share & -0.1666 & -0.1269 & $-0.2522^{* *}$ & $-0.2258^{* * *}$ \\
\hline Current Ratio & 0.1703 & -0.5898 & $-3.3109^{* *}$ & $-0.2245^{\star * *}$ \\
\hline Quick Ratio & -0.1497 & $-0.1686^{*}$ & $-0.3262^{*}$ & -0.3621 \\
\hline
\end{tabular}

Notes: $1 .{ }^{\star \star \star}$ denotes statistical significance at $1 \%$ level. $2 .{ }^{\star \star}$ denotes statistical significance at $5 \% .3 .{ }^{\star}$ denotes statistical significance at $10 \%$.

\section{Conclusion}

When a company faces patent infringement suit, this may lead to negative perceptions of investors or insider shareholders. Besides future challenge from the suit, high litigation cost would reduce revenue. The event may become arbitrage investment opportunity. After the event, reverse correction is conducted, and stock price would be rational. However, in Taiwan market, patent infringement suit is regarded negative news for plaintiff and defendant. The empirical results suggest that the suit reported on newspapers is second-hand news, and investors have no obvious reaction. However, the occurrence of the suit is regarded negative news for the companies. The reaction from plaintiffs is not obvious. For defendants, lawsuit requires high legal fee cost, and has adverse impact on corporation reputation, so defendants have obvious reaction.

In lawsuits by vendors, stock price has strong volatility, while the lawsuits by purchasers and industry competitors have a consistent negative impact. This implies that the lawsuits by the upstream against the downstream and lawsuits in the same industry have adverse impact on company stock price. In lawsuits by potential competitors, the investors are confident about the defendants. However, other lawsuit sources have negative impacts, and may affect the stock price. Hence, patent infringement lawsuits can lead to negative perceptions of investors or insider shareholders, and have adverse impact on the future operation of the companies. Patent infringement lawsuits have adverse impact on stock price, and make investors loss confidence on the companies, in turn, affect stock price. After the event, a reverse correction is conducted, and stock price becomes normal, thus bringing investors an arbitrage opportunity. Generally, patent infringement lawsuit is bad news for companies.

In cross-section multiple regression analysis, significance level is not reached in lawsuits by vendors, and perhaps other influencing factors exist. In lawsuits by purchasers, patent 
infringement behaviour has a significant negative impact on inventory turnover rate, and inventory may be affected if purchasers file a suit. In lawsuits by industry competitors, many indictors show a negative impact (return on total assets ratio, operating income rate, earnings per share, current ratio, and total assets turnover). The lawsuits by industry competitors have a significant impact on enterprises, while lawsuits by potential competitions have a positive impact on earnings per share. In conclusion, the patent infringement lawsuits by potential competitors can lead to positive earnings per share, and provide an arbitrage opportunity.

\section{Acknowledgment}

We would like to thank the anonymous referees for helpful comments and suggestions, and Yi-Hsien Wang also would like to thank the National Science Council of Taiwan for financially supporting this research under Contract No. NSC 100-2410-H-034-004.

\section{References}

Agarwal, R.; Ganco, M.; Ziedonis, R. H. 2009. Reputations for toughness in patent enforcement: implications for knowledge spillovers via inventor mobility, Strategic Management Journal 30: 1349-1374. http://dx.doi.org/10.1002/smj.792

Agliardi, E.; Agliardi, R. 2011. An application of fuzzy methods to evaluate a patent under the chance of litigation, Expert Systems with Applications 38: 13143-13148.

http://dx.doi.org/10.1016/j.eswa.2011.04.122

Asgharian, H.; Holmfeldt, M.; Larson, M. 2011. An event study of price movements following realized jumps, Quantitative Finance 11: 933-946. http://dx.doi.org/10.1080/14697680903369518

Banks, D. W.; Kinney, W. R. 1982. Loss contingency reports and stock prices: an empirical study, Journal of Accounting Research 20: 240-254. http://dx.doi.org/10.2307/2490773

Bessen, J. E.; Meurer, M. J. 2006. Patent litigation with endogenous disputes, American Economic Review 96: 77-81. http://dx.doi.org/10.1257/000282806777212288

Bhagat, S.; Romano, R. 2002. Event studies and the law: part II: empirical studies of corporate law, American Law and Economics Review 4: 380-423. http://dx.doi.org/10.1093/aler/4.2.380

Brown, S. J.; Warner, J. B. 1985. Using daily stock returns: the case of event studies, Journal of Financial Economics 14: 3-31. http://dx.doi.org/10.1016/0304-405X(85)90042-X

Campbell, C. J.; Cowan, A. R.; Salotti, V. 2010. Multi-country event study methods, Journal of Banking \& Finance 34: 3078-3090. http://dx.doi.org/10.1016/j.jbankfin.2010.07.016

Capik, P.; Drahokoupil, J. 2011. Foreign direct investments in business services: transforming the visegrád four region into a knowledge-based economy?, European Planning Studies 19: 1611-1631. http://dx.doi.org/10.1080/09654313.2011.586181

Chen, S. S.; Su, X. Q. 2010. Market reaction to entry timing of corporate capital investment announcement: evidence from announcement-period abnormal returns and analysts' earnings forecast revisions, Oxford Bulletin of Economics and Statistics 60: 485-507.

Chen, Y. S.; Chang, K. C. 2010. The relationship between a firm's patent quality and its market value - the case of US pharmaceutical industry, Technological Forecasting and Social Change 77: 20-33. http://dx.doi.org/10.1016/j.techfore.2009.06.003

Cheung, A. W. K. 2011. Do stock investors value corporate sustainability? Evidence from an event study, Journal of Business Ethics 99: 145-165. http://dx.doi.org/10.1007/s10551-010-0646-3 
Chiu, Y. J.; Chen, Y. W. 2007. Using AHP in patent valuation, Mathematical and Computer Modelling 46: 1054-1062. http://dx.doi.org/10.1016/j.mcm.2007.03.009

Chuang, C. C.; Wang, Y. H. 2010. Electoral information in developed stock market: testing conditional heteosecdasticity in the market model, Applied Economics 42: 1125-1131. http://dx.doi.org/10.1080/00036840701721117

Cockburn, I. M.; MacGarvie, M. J. 2009. Patents, thickets and the financing of early-stage firms: evidence from the software industry, Journal of Economics \& Management Strategy 18: 729-773. http://dx.doi.org/10.1111/j.1530-9134.2009.00228.x

Cohen, W. M.; Goto, A.; Nagata, A.; Nelson, R. R.; Walsh, J. P. 2002. R\&D spillovers, patents and the incentives to innovate in Japan and the United States, Research Policy 31: 1349-1367. http://dx.doi.org/10.1016/S0048-7333(02)00068-9

Corhay, A.; Tourani, R. A. 1994. Statistical properties of daily returns: evidence from European stock markets, Journal of Business Finance \& Accounting 21: 271-282. http://dx.doi.org/10.1111/j.1468-5957.1994.tb00318.x

David, P. A.; Foray, D. 2002. An introduction to the economy of the knowledge society, International Social Science Journal 54: 9-23. http://dx.doi.org/10.1111/1468-2451.00355

Ernst, H.; Legler, S.; Lichtenthaler, U. 2010. Determinants of patent value: insights from a simulation analysis, Technological Forecasting and Social Change 77: 1-19. http://dx.doi.org/10.1016/j.techfore.2009.06.009

Fama, E. F.; Fisher, L.; Jensen, M.; Roll, R. 1969. The adjustment of stock prices to new information, International Economic Review 10: 1-21. http://dx.doi.org/10.2307/2525569

Frost, C. A. 1991. Loss contingency reports and stock prices: a replication and extension of banks and Kinney, Journal of Accounting Research 29: 157-169. http://dx.doi.org/10.2307/2491034

Galasso, A.; Schankerman, M. 2010. Patent thickets, courts, and the market for innovation, RAND Journal of Economics 41: 472-503. http://dx.doi.org/10.1111/j.1756-2171.2010.00108.x

Godin, B. 2004. The new economy: what the concept owes to the OECD, Research Policy 33: 679-690. http://dx.doi.org/10.1016/j.respol.2003.10.006

Hall, L. A.; Bagchi-Sen, S. 2002. A study of R\&D intensity, innovation and business performance in the Canadian biotechnology industry, Technovation 22: 231-244.

http://dx.doi.org/10.1016/S0166-4972(01)00016-5

Hirschey, M.; Richardson, V. J. 2001. Valuation effects of patent quality: a comparison for Japanese and U.S. firms, Pacific-Basin Finance Journal 9: 65-82. http://dx.doi.org/10.1016/S0927-538X(00)00038-X

Jang, W. Y.; Chen, C. T. 2009. Defendant firms and response to legal crises: effect on shareholder value, Journal of Contingencies and Crisis Management 17: 108-117.

http://dx.doi.org/10.1111/j.1468-5973.2009.00570.x

Koku, P. S.; Qureshi, A. A.; Akhigbe, A. 2001. The effects of news on initial corporate lawsuits, Journal of Business Research 53: 49-55. http://dx.doi.org/10.1016/S0148-2963(00)00184-3

Konchitchki, Y.; O'Leary, D. E. 2011. Event study methodologies in information systems research, International Journal of Accounting Information Systems 12: 99-115. http://dx.doi.org/10.1016/j.accinf.2011.01.002

Lai, J. H.; Chang, S. C.; Chen, S. S. 2010. Is experience valuable in international strategic alliances?, Journal of International Management 16: 247-261. http://dx.doi.org/10.1016/j.intman.2010.06.004

Langinier, C.; Marcoul, P. 2009. Contributory infringement rule and patents, Journal of Economic Behavior \& Organization 70: 296-310. http://dx.doi.org/10.1016/j.jebo.2008.10.012

Lanjouw, J. O.; Schankerman, M. 2001. Characteristics of patent litigation: a window on competition, RAND Journal of Economics 32: 129-151. http://dx.doi.org/10.2307/2696401 
Lanjouw, J. O.; Schankerman, M. 2004. Patent quality and research productivity: measuring innovation with multiple indicators, Economic Journal 114: 441-465.

http://dx.doi.org/10.1111/j.1468-0297.2004.00216.x

Li, S.; Tallman, S. 2011. MNC strategies, exogenous shocks, and performance outcomes, Strategic Management Journal 32: 1119-1127. http://dx.doi.org/10.1002/smj.918

Lin, C. T.; Wang, Y. H.; Lin, W. R. 2008. Information effect of top executive turnover: testing hybrid grey-market model, Journal of Grey System 20(1): 53-64.

Lo, S. T. 2011. Strengthening intellectual property rights: experience from the 1986 Taiwanese patentreforms, International Journal of Industrial Organization 29: 524-536. http://dx.doi.org/10.1016/j.ijindorg.2010.11.001

Malerba, F.; Nelson, R. 2011. Learning and catching up in different sectoral systems: evidence from six industries, Industrial and Corporate Change 20: 1645-1675. http://dx.doi.org/10.1093/icc/dtr062

Marco, A. C. 2005. The option value of patent litigation: theory and evidence, Review of Financial Economics 14: 323-351. http://dx.doi.org/10.1016/j.rfe.2004.09.003

Megna, P.; Klock, M. 1993. The impact of intangible capital on Tobin's Q in the semiconductor industry, American Economic Review 83: 265-269.

Pantzalis, C.; Stangeland, D. A.; Turtle, H. J. 2000. Political elections and the resolution of uncertainty: the international evidence, Journal of Banking and Finance 24: 1575-604.

http://dx.doi.org/10.1016/S0378-4266(99)00093-X

Porter, M. E. 1980. Competitive strategy: techniques for analyzing industries and competitors. New York: Free press.

Raghu, T. S.; Woo, W.; Mohan, S. B.; Rao, H. R. 2008. Market reaction to patent infringement litigations in the information technology industry, Information Systems Frontiers 10: 61-75.

http://dx.doi.org/10.1007/s10796-007-9036-5

Shane, S.; Somaya, D. 2007. The effects of patent litigation on university licensing efforts, Journal of Economic Behavior \& Organization 63: 739-755. http://dx.doi.org/10.1016/j.jebo.2006.05.012

Sharpe, W. 1964. Capital asset prices: a theory of market equilibrium under conditions of risk, Journal of Finance 19: 425-442. http://dx.doi.org/10.2307/2977928

Shinn, T. 2002. The triple helix and new production of knowledge: prepackaged thinking in science and technology, Social Studies of Science 32: 599-614. http://dx.doi.org/10.1177/030631202128967271

Siebert, R.; Graevenitz, G. V. 2010. Jostling for advantage or not: choosing between patent portfolio races and ex ante licensing, Journal of Economic Behavior \& Organization 73: 225-245. http://dx.doi.org/10.1016/j.jebo.2009.09.002

Somaya, D. 2003. Strategic determinants of decisions not to settle patent litigation, Strategic Management Journal 24: 17-38. http://dx.doi.org/10.1002/smj.281

Suzuki, J. 2011. Structural modeling of the value of patent, Research Policy 40: 986-1000. http://dx.doi.org/10.1016/j.respol.2011.05.006

Tseng, C. H.; Cheng, S. T.; Wang, Y. H. 2009. New hybrid methodology for stock volatility prediction, Expert Systems with Applications 36(2): 1833-1839. http://dx.doi.org/10.1016/j.eswa.2007.12.004

Velmurugan, M. S. 2010. Revisiting accounting in the knowledge-based economy, Journal of the Knowledge Economy 1: 318-332. http://dx.doi.org/10.1007/s13132-010-0017-4

Wagner, S.; Cockburn, I. 2010. Patents and the survival of Internet-related IPOs, Research Policy 39:214-228. http://dx.doi.org/10.1016/j.respol.2009.12.003

Yang, F. J.; Wang, Y. H.; Chen, L. J. 2010. The information value of the infectious diseases outbreak on biotechnology, Journal of Medicinal Plants Research 4: 2103-2107. 
Jun-De LEE is an Assistant Professor at the Department of International Business, Minghsin University of Science and Technology in Taiwan. His research interests include macroeconomics and finance.

Yi-Hsien WANG is an Associate Professor at the Department of Banking \& Finance, Chinese Culture University in Taiwan, and holds PhD in the Graduate School of Management, Ming Chuan University in Taiwan. His current research interests are in the area of financial management, decision science and industry competitive analysis.

Ching-Wen LIN is an Associate Professor at the Department of International Business Administration, Chinese Culture University, Taiwan. She received a Doctoral Degree from Nova Southeastern University and an MS Degree from the University of Illinois. Her recent publications have appeared in the International Journal of Electronic Finance, International Journal of Technology Management, Industrial Management and Data Systems, Total Quality Management \& Business Excellence, International Journal of Technology Management, and International Journal of Manufacturing Technology and Management.

Hsin-Ham LIN is MBA student of Graduate Institute of International Business Administration, Chinese Culture University in Taiwan. His research interests include financial management and industry competitive analysis. 